Periodicals, published by the National Central Library. It is hoped that it will be possible to prepare 5- and 10-year compilations, offering to the user the convenience of the present compilation and incorporating the name World List in the title. Bucop employs a computerized system and the National Central Library commands resources commensurate with the immense amount of material which it will be necessary to handle.

The possibility of providing an index, to assist (for example) in tracing a periodical the title of which is incompletely known, is being borne in mind by the compilers of the computerized catalogue. It could hardly be expected within the framework of the World List as it is to-day. This edition is not absolutely free of errors, but it is clear that it has been most meticulously prepared. It is obviously impossible to guarantee the inclusion of every scientific periodical in a list compiled from information volunteøred by contributing libraries the stocks of which may not include every publication that could qualify. However, the number of libraries contributing to the present edition has been increased and, by courtesy of the Director, the compilers have had access to a number of titles held in the National Lending Library for Science and Technology, which was not officially opened until 1962.

Many new journals have been started since 1960, but nevertheless these three volumes provide an invaluable guide to all but a small fraction of the periodical literature a scientist may wish to consult, and to its whereabouts in British libraries.

\title{
FIELD STUDIES COUNCIL
}

1 CCORDING to the latest annual report of the Field A Studies Council*, the year 1963-64 saw a continuance of the growth in the number of students attending the Council's centres. The total number of student-weeks reached 11,617 (an increase of 12 per cent)--mainly as a result of edditional accommodation at Slapton Ley and of a full season at Orielton, but also because of larger bookings at other centres. This was divided between subjects as follows:

$\begin{array}{lr}\text { Biological subjects } & 5,979 \\ \text { Countryside and natural history } & 292 \\ \text { Geographical and geological } & 4,686 \\ \text { Art } & 245 \\ \text { Archaeology } & 219 \\ \text { Other courses } & 196\end{array}$

The number of individual attendances as distinct from the number of student weeks was 11,629, divided as follows:

$\begin{array}{lr}\text { Sixth forms } & 7,736 \\ \text { Other forms } & 192 \\ \text { Training colleges and teacher courses } & 1,569 \\ \text { Universities } & 1,160 \\ \text { Technical colleges } & \mathbf{1 4 5} \\ \text { Amateurs } & 827\end{array}$

Despite the extra numbers which the centres have been able to take, many hundreds of would-be students had to be turned away. It is the Council's aim and intention to open further centres when the necessary finance becomes available, and the New Centres Working Party is con-

- Field Studies Council. Annual Report, 1963-1964. IPp. 39+8 fphotographs. (London: Field Studies Council, 1965.) tinuing its search for suitable properties in areas where centres might be established. The Council was greatly heartened in the early part of the year to learn that the Worshipful Company of Drapers was proposing to make a grant of $£ 25,000$ to it to mark the occasion of the sexcentenary of the granting of the Company's first charter. Payment is to be made by instalments over a period of not more than five years; a condition of the grant is that it shall be used for purchasing and converting a property situated in North Wales to a field studies centre. Search immediately began for a suitable building. It was decided that the property most suitable to the Council's requirements was Rhyd-y-Creua, a house situated in the Conway Valley, one mile from Betws-yCoed. Rhyd-y-Creua is unlikely to be ready to accommodate students before the 1966 season commences.

Following the recommendation of the Scientific Advisory Committee, Preston Montford and Slapton Ley have bren inspected by the Department of Education and Science, the reports of which are now being awaited. Preston Montford was also visited by two scientists from the Sub-committee and as a result of their report and suggestions a new experimental biology course was in. augurated which, after one season, is considered to be very successful.

A small working party has been set up, the brief of which is to consider the educational aims and practice of the Field Studies Council in the light of present and future needs and to make recommendations to the Council.

\section{PHILOSOPHIES OF PIERRE TEILHARD DE CHARDIN}

\begin{abstract}
FIRST met Pierre Teilhard de Chardin as a young man, when we were assisting in prehistoric investigations in north Spain in 1912 or thereabouts. I also had occasion to see him from time to time until his death. $\mathrm{He}$ had a charming personality and was an excellent research worker in the fields of palaeontology and geology, and did much administrative work while living in China. He read deeply in the realm of philosophy, and was accepted wholeheartedly by others practising in that discipline. Above all, he was a profound Christian-a Roman Catholic and indeed a Jesuit. Not many men have reached the front rank in all these three disciplines, and therefore what he has to say is worthy of great consideration.
\end{abstract}

Teilhard was a firm believer in evolution-indeed, he was to some extent persecuted by his own hierarchy for this belief-but he did not confine evolution to living organisms; for him everything from the atom to reflective man has been influenced by evolution. He made no distinction between man and the animals, nor indeed between animate and inanimate objects. Matter had 'pre-life', an imperceptible particle of life, and was therefore also influenced by evolution. At present the effects of evolution tend to divergence, but in the case of reflective man must ultimately converge towards a unity which he called omega. For Teilhard this omega was equated with the incarnation, birth, life, death and resurrection of Jesus, the Christ.

Such a bald series of statements is, of course, grossly inadequate. It takes many hours of hard study properly to appreciate the width and depth of Teilhard's thought. It is a great pity that the older generation of Jesuits in 
the 'twenties failed to recognize what a great man he was. They seldom allowed him to come to Paris, and he mostly lived and worked outside his native France. Ho died in 1955 in the Unitod States. Only after his death was it possible for his great books to be properly produced. The Abbé Brouil once told me that what he was able to publish during his lifotime was only bocauso he chanced to bo a friend of the thon Pope. Several times friends suggested that he should cease to be a Jesuit. But Pèro Toilhard was loyal both to his Church and to his Order. Pierre Teilhard de Chardin-S'ome Aspects of his Thought* is an admirable introduction to certain aspects

* Proceedings of the University of Newcastle upcn Tyne Philosophical Society. Vol. 1. No. 3: Pierre Teilhard de Chardin-Some Aspects of his Thought. P. G. Fothergill. Pp. 24-34. (Newcastle upon Tyne: University of Newcastle upon Tyne Philosophical Society.) of his philosophies. It should be read before attempting to tackle the great life by Claude Cuénot, or indeed the two major works of Teilhard himself, namely, The Phenomenon of Man and Le Milieu Divin (tho Fronch title has been retained in the English translation). Not evoryone after careful study will entirely agree with Teilhard's thought. There will always be those who separate entirely the soul of man from the rest of creation and treat it like the mistletoe on an applo tree, which for a time is bound to the troe yet is really totally distinct. But Teilhard's philosophy is worthy of vory careful thought, and anyone interested cannot do better than to read carefully Fothorgill's Pierre Teilhard de Chardin: Some Aspects of his Thought.

M. C. BurkitTt

\title{
ONCOLYSIS WITH LASER ENERGY COMBINED WITH CHEMOTHERAPY
}

\author{
By JOHN PETER MINTON \\ Surgery Branch \\ AND \\ Prof. GEORGE H. WEISS and Prof. MARVIN ZELEN \\ Biometry Branch, National Cancer Institute, National Institutes of Health, Bethesda, Maryland
}

$\mathrm{R}^{\mathrm{E}}$ ECENT experiments have shown that pulsed laser energy can be used for the rapid and precise destruction of malignant tumour implants in animal systems ${ }^{1}$ It has been shown quantitatively that the probability of destroying a tumour implant in a mouse depends on the ratio of laser encrgy to tumour size. 'The destruction probability increases with this ratio in a mannor which can be made mathematically precise ${ }^{2}$.

It is the purpose of this article to report on experiments where chemotherapy has significantly increased the destructive effect of laser energy on the tumour system. Other investigators ${ }^{3,1}$ have also attempted to find a way for potentiating the destructive effects of the laser energy on tumour systems. These investigations involved painting the surface of a tumour with a dye or systemically injecting various pigmented solutions into the animal. The results by these mothods have been relativoly unsuccessful.

The results of experiments comparing the effect of laser energy alone with the combination of laser onergy and a course of cyclophosphamide on tumour-bearing mice are summarized here. The results show that permanent tumour destruction by laser energy is significantly increased in mice receiving cyclophosphamide as compared with mice not receiving this course of chemotherapy.

The experiment consisted of injecting 115 six-weok-old $C D F_{1}$ fomale mice with 0.04 c.c. of $a 1: 10$ dilution of Cloudman $\$ 91$ melanoma. At the end of two weeks of tumour growth, the animals were arranged in order of size of tumour which ranged from $1 \mathrm{~mm}$ to $10 \mathrm{~mm}$ in diametor. The animals woro paired according to size such that animals in a pair had tumours of comparable size. Among the 57 pairs, 11 pairs were designated as 'control pairs'; the remaining 46 were termed 'treatmont pairs'. 'The control pairs were assigned to every fifth pair in order of size of tumour. One animal in each of the control and treatment pairs then received an 11-day course of cyclophosphamido chemotherapy injected subcutaneously at a daily dosage of $25 \mathrm{mg} / \mathrm{kg} / \mathrm{day}$. At the end of the fifth or sixth day of chemotherapy, all the animals in the treatment pairs were exposed to laser energy. Animals in the same pair recoived the samn amount of energy from a ruby laser (6869 Laser Unit-Maser Optics, Boston, Mass.). The ruby rod was $1.6 \mathrm{~cm}$ in diameter and $17.7 \mathrm{~cm}$ in length and utilized a Fabry-Perot etalon dielectric coating for internal reflexion. It was stimulated by two $7.5 \mathrm{~kW}$ xenon flash lamps. The laser energy was delivered in several pulses, each of which was $48-56$ joules. Energy determinations were obtained by direct calorimetry at varying intervals between the series of tumour exposures. Fach laser pulse was delivered through a biconvex lens with a $12.5 \mathrm{~cm}$ focal length.

In order to destroy a tumour, it is nocessary that the entire tumour be exposed to laser energy. Therefore, large tumours (greater than $5 \mathrm{~mm}$ in diameter) received multiple pulses. Animals were observed for five weeks after exposure to the laser cnergy.

There were 42 treatment pairs in which results could be evaluated; the death of two mice invalidated results from two other pairs. These rosults are summarized in Table 1.

The only experimental results which can bo used for evaluating the comparison botween the two treatments are those pairs in which the tumour on one mouse was destroyed, while the other mouse's tumour rocurred.

There were 15 such pairs. Of these, 14 showod tumour destruction by the combination of laser and chemotherapy with tumour recurrence on the paired mouse which recoived laser only. Clearly this is a highly significant result.

The effect of chemotherapy before irradiation by laser energy was to decrease the growth rate of the timmour. Consequently at the time of laser radiation, the animals receiving chemotherapy had tumours which were (on the average) slightly smaller than those receiving no chemotherapy. The average (geometric) diameters were $8.27 \mathrm{~mm}$ and $7.92 \mathrm{~mm}$ for the non-chemotherapy and chemotherapy animals respoctively.

In order to determine if the slight difference in tumour size could possibly account for the potentiation observed with the chemotherapy, the animals were paired a second time (after boing exposed to the laser energy). The animals in the same pair received the same amount of laser energy, but this time the (geometric) diameters of the tumour at the time of laser exposure were matched. This classification yieldod pairs, in which tho averagt

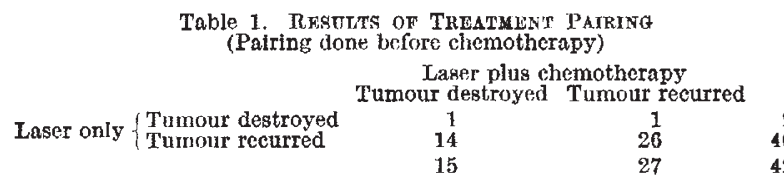

